\title{
PENDIDIKAN AGAMA ISLAM SEBAGAI PENANGGULANGAN PROBLEMATIKA REMAJA SELAMA PANDEMI COVID-19
}

\author{
RATNAWATI \\ MTs Negeri Luwu Utara, Sulawesi Selatan \\ E-mail: ratnabintang2@gmail.com
}

\begin{abstract}
ABCTRACT
This research will discuss the role of Islamic religious education as a solution to adolescent problems during the Covid-19 pandemic. The method used in this research is library research method using documentation techniques and qualitative analysis methods. Based on these data, it was found that all adolescent problems that arose during the Covid-19 pandemic, both physical and mental problems could be overcome by the application and practice of Islamic religious values and teachings obtained through education. Islamic religious education which does not only focus on theoretical matters, but is further on how Islamic religious values and teachings can be realized in the lives of adolescents. In Islam, education has a very broad scope, ranging from religious, physical, mental to moral education. That is why providing Islamic religious education for adolescents in the midst of this pandemic can be a solution in overcoming all the problems they are experiencing during the Covid-19 pandemic.
\end{abstract}

Keyword: Education, Islam, Adolescent, Covid-19.

\begin{abstract}
ABSTRAK
Penelitian ini akan mendiskusikan mengenai bagaimana peran pendidikan agama Islam sebagai penanggulangan problematika remaja selama masa pandemi Covid-19. Metode yang digunakan dalam penelitian ini adalah metode penelitian kepustakaan dengan menggunakan teknik dokumentasi serta metode analisis kualitatif. Berdasarkan data-data tersebut, ditemukan bahwa segala permasalahan remaja yang muncul selama pandemi Covid-19 ini berlangsung, baik itu permalahan yang menyangkut fisik maupun mental mereka dapat diatasi dengan penerapan dan pengamalan nilai-nilai dan ajaran agama Islam yang diperoleh melalui pendidikan. Pendidikan agama Islam yang tidak hanya berfokus pada hal-hal teoritis semata, namun lebih jauh kepada bagaimana nilai-nilai dan ajaran agama Islam bisa terealisasi dalam kehidupan remaja. Dalam Islam, pendidikan memiliki cakupan yang sangat luas, mulai dari pendidikan keimanan, fisik, mental hingga pada pendidikan akhlak. Oleh karena itulah mengapa pemberian pendidikan agama Islam bagi remaja di tengah-tengah masa pandemi ini bisa menjadi solusi dalam mengatasi segala permasalahan yang sedang mereka alami di masa pandemi Covid-19 ini.
\end{abstract}

Kata Kunci: Pendidikan, Islam, Remaja, Covid-19.

\section{PENDAHULUAN}

Kehadiran virus Covid-19 di hampir seluruh penjuru dunia selama kurang setahun belakangan ini memberikan dampak perubahan yang tidak sedikit bagi kehidupan umat manusia. Perubahan ini terjadi hampir di setiap aspek kehidupan manusia. Dimulai dari tingkat populasi umat manusia yang berkurang drastis sejak kemunculan virus ini hingga proses pembelajaran yang dipaksa beralih ke sistem daring guna mencegah penyebaran virus Covid19 ini dan hal ini tentunya berlaku di seluruh dunia.

Peralihan sistem pembelajaran yang mulanya dilakukan dengan tatap muka di sekolah ke sistem pembelajaran daring ternyata memberikan dampak signifikan bagi kehidupan remaja. Sebuah survey yang dilakukan oleh Child Mind Institute mengungkapkan bahwa para orang tua menyaksikan bagaimana pandemi ini sangat mempengaruhi kesehatan fisik dan mental anak mereka. Dikemukakan bahwa kecemasan (40\%) dan depresi (37\%) merupakan hal yang paling banyak dialami oleh para remaja selama proses pembelajaran daring dilakukan (2020 Children's Mental Health Report: Telehealth in an Increasingly Virtual World | Child Mind Institute, n.d.). Selain itu, pembelajaran daring yang sangat bergantung pada penggunaan 
smartphone dan internet membuat para remaja kesusahan dalam mengatur waktu mereka sehingga membuat mereka adiktif dan abai terhadap hal-hal diluar smartphone mereka (Truzoli et al., 2020).

Segala permasalahan yang ditimbulkan pandemi covid-19 ini terhadap para remaja tidak bisa terlepas dari karakteristik remaja itu sendiri. Masa remaja dikenal dengan masa persimpangan antara masa anak-anak menuju ke masa dewasa (Daradjat, 1977). Pada masa ini, remaja tidak hanya mengalami perubahan drastis pada fisik mereka, tetapi juga perubahan pada psikis mereka. Remaja mulai melepaskan diri dari ikatan dengan orang tua mereka dan mulai beradaptasi dengan lingkungan sosial dan masyarakat yang ada di sekitar mereka (Subur, 2016). Hal ini ditambah dengan kecenderungan remaja yang sangat mudah terpengaruh oleh lingkungan sosial tanpa mempertimbangkan efek yang akan mereka terima nantinya (Ameliola $\&$ Nugraha, 2013). Oleh karena itu, perubahan drastis yang dibawa oleh virus Covid-19 ini bisa sangat mempengaruhi remaja, khususnya terhadap kesehatan mental mereka dan bagaimana mereka mengisolasi diri dari lingkungan masyarakat yang ada di sekitar mereka disebabkan sifat adiktif terhadap ponsel mereka yang semakin menjadi-jadi selama pandemi Covid-19 ini. Hal ini dikarenakan kecenderungan usia dan kerentanan mental mereka.

Permasalahan ini tentunya tidak bisa dibiarkan berlarut-larut. Segala gangguan yang diterima oleh remaja, baik itu secara fisik maupun mental akan sangat memengaruhi tumbuh kembang mereka. Remaja adalah harapan bangsa dan agama karena kelak merekalah yang akan melanjutkan estafet perjuangan dan pembangunan agama, bangsa dan negara. Oleh karena itu, dalam konteks ini persiapan dan pematangan diri remaja haruslah dilakukan. Persiapan diri, baik secara fisik maupun mental akan diterima oleh para remaja melalui pendidikan yang sesuai. Pendidikan yang bisa memberikan bekal bagi mereka untuk menghadapi segala permasalahan yang muncul selama pandemi ini berlangsung.

Model pendidikan yang paling cocok dan sesuai dengan kebutuhan remaja selama pandemi ini adalah pendidikan agama Islam. Hal ini dikarenakan kehadiran agama sangat erat hubungannya dengan usaha untuk menciptakan hidup bahagia (Alim, 2011), yang di mana hidup bahagia ini akan membantu mereka untuk menghadapi segala permasalahan selama pandemi virus Covid-19 ini. Bagi jiwa yang mengalami kegelisahan, agama akan memberi jalan dan menjadi penyejuk rohani. Banyak yang sudah membuktikan bahwa dengan beragama dan menjalankan ajaran agama memberikan ketenangan jiwa (Daradjat, 1988). Pendidikan agama Islam bukan hanya sebuah bentuk pendidikan yang diajarkan guna mendapatkan nilai atau penghafalan dalil-dalil dan tata ibadah saja, tetapi pendidikan agama Islam lebih memusatkan perhatiannya pada pembentukan akhlak dan budi pekerti yang baik, yang pada akhirnya memberikan dampak positif terhadap pribadi remaja yang mengarah pada pemahaman dan pengaktualisasian keimanan yang menciptakan kecerdasan baik itu secara intelektual, emosional maupun spiritual (Minarti, 2016).

Berdasarkan fakta-fakta tersebut, penanaman dan penerapan nilai-nilai dan ajaran agama Islam yang diterima melalui pendidikan yang komprehensif kelak akan membantu mereka mempersiapkan diri dalam menghadapi hal-hal di luar kehendak mereka dan hal ini juga termasuk segala permasalahan yang kini mereka hadapi akibat masa pandemi Covid-19 yang tidak kunjung berakhir.

\section{METODE PENELITIAN}

Penelitian ini menggunakan metode penelitian kepustakaan atau yang dikenal juga dengan metode literatur untuk menganalisis bagaimana peran pendidikan agama Islam sebagai penanggulangan problematika remaja selama pandemi Covid-19 berlangsung. Pada penelitian ini, teknik dokumentasi dijadikan sebagai teknik pengumpulan data di mana data-data yang dikumpulkan adalah data-data yang berhubungan dengan permasalahan pendidikan agama Islam dan problematika remaja selama pandemi Covid-19. Data-data tersebut didapat melalui berbagai sumber, baik itu melalui buku-buku, artikel-artikel online maupun cetak. Data-data ini kemudian dianalisis menggunakan teknik data kualitatif dengan penyajian data secara deskriptif 
dengan tujuan agar data-data tersebut bisa dipaparkan secara mendalam, terperinci dan mendetail.

\section{HASIL DAN PEMBAHASAN}

1. Remaja Dalam Kerankeng Pandemi Covid-19

Fase remaja merupakan fase yang sangat menentukan dalam pertumbuhan dan perkembangan seseorang. Fase remaja ini merupakan fase di mana terjadinya transisi dari fase anak-anak menuju dewasa dan merupakan fase perpanjangan fase anak-anak sebelum ia mencapai dewasa (Daradjat, 1977). DeBrun juga mengartikan remaja dengan periode pertumbuhan antara masa kanak-kanak dan dewasa (Jahja, 2011). Kata remaja sendiri berasal dari bahasa Latin yaitu adolescene yang diartikan dengan to grow atau to grow maturity. Berkaitan dengan ini, Yulia Singgih menggunakan istilah adolensia dengan mengacu pada remaja dalam arti yang luas. Menurutnya, remaja merupakan masa peralihan yang terjadi antara masa anak-anak dan masa dewasa dan ini terjadi antara ketika ia menginjak usia 12 tahun hingga 21 tahun. Hal ini menegaskan bahwa fase remaja ini merupakan fase di mana anak-anak bertumbuh dan berkembang menjadi dewasa.

Berbicara mengenai batas usia kapan dimulainya masa remaja dan kapan berakhirnya masa ini, beberapa ahli terlihat berbeda pendapat. Jamaluddin Mahfudz (Mahfuzh, 2001) mengutarakan bahwa usia 12 tahun sampai 15 tahun disebut dengan fase permulaan remaja, usia 15 tahun hingga 18 tahun disebut dengan fase pertengahan remaja, usia 18 tahun sampai dengan usia 22 tahun disebut dengan fase paripurna remaja, dan usia 22 tahun sampai 30 tahun sebagai fase kematangan dan pemuda. Pada tahun 1974, WHO memberikan definisi mengenai remaja dengan lebih mengacu pada tiga aspek, yaitu biologis, psikologis dan sosial ekonomi. Remaja diartikan sebagai suatu masa di mana; 1) Individu berkembang dan bertumbuh sejak pertama kali ia mengalami perubahan tanda-tanda seksual sekundernya hingga ia mencapai kematangan seksual; 2) Individu yang mengalami perkembangan psikologis dan mulai mengidentifikasi diri dari anak-anak menjadi dewasa; dan 3) Terjadinya peralihan dari ketergantungan pada orang tua secara finansial menuju keadaan yang lebih relatif mandiri. Seiring berjalannya waktu WHO kemudian menetapkan usia remaja, yakni 10-20 tahun. Hal ini berdasarkan pertimbangan tentang Kesehatan remaja di mana banyaknya terjadi kehamilan yang terlalu awal. Di samping itu, PBB menetapkan batas usia 15-24 sebagai batas usia remaja dalam rangka keputusan mereka menetapkan tahun 1985 sebagai Tahun Pemuda Internasional (Sarwono, 2012).

Adapun mengenai perkembangan selama masa remaja, Sebagian ahli psikologi menyatakan bahwa masa remaja terdiri atas tiga subperkembangan, yaitu: 1) subperkembangan prapuber, hal ini terjadi sekitar kurang lebih dua tahun sebelum masa puber; 2) subperkembangan puber, masa ini terjadi selama dua setengah sampai tiga setengah tahun, dan 3) subperkembangan post puber, masa ini terjadi di saat perkembangan biologis melambat namun masih terus berlangsung di bagian-bagian organ tertentu. Masa ini merupakan masa akhir remaja di mana mereka mulai menampakkan tanda-tanda kedewasaan (Tohirin, 2005). Masa-masa perkembangan remaja sebagaimana yang diterangkan oleh para ahli makin menegaskan bagaimana rumit dan membingungkannya masa itu, khususnya bagi remaja itu sendiri yang sedang menjalani dan mengalami masa itu.

Proses transisi yang dialami oleh remaja ini tentunya menggiring mereka kepada ketidakjelasan akan identitas diri mereka. Satu sisi mereka masih anak-anak, namun di lain sisi mereka sudah harus bertingkah laku layaknya orang dewasa. Dalam usahanya untuk mencari jati diri, seorang remaja sering kali terlibat perselisihan dengan orang tua mereka. Hal ini terjadi karena pada saat itu mereka sudah memiliki pendapat-pendapat sendiri, begitu pula dengan cita-cita serta nilai-nilai sendiri yang berbeda dengan apa yang dimiliki oleh orang tua mereka (Sarwono, 2012). Perselisihan-perselisihan ini lebih rinci dijelaskan oleh Yahya (Jahja, 2011) terjadi karena beberapa alasan, yakni: 1) pada masa ini, remaja sudah mulai merasakan kebebasan dan haknya untuk bisa mengutarakan pendapatnya sendiri akan 
suatu permasalahan; 2) Remaja pada masa ini juga sangat terpengaruh dengan temantemannya begitu pula dengan lingkungannya, sehingga membuat pengaruh orang tua mereka melemah; 3) Masa remaja merupakan masa di mana terjadi perubahan secara besar-besaran pada fisik dan juga psikis mereka, terutama berkaitan dengan pertumbuhan seksualitasnya. Perasaan-perasaan yang ditimbulkan oleh perubahan drastis ini tentunya memunculkan kebingungan dan bisa jadi menjadi sumber perasaan bersalah dan frustasi; 4) Pada masa ini, remaja terkadang memiliki sifat percaya diri yang berlebih dan hal ini terjadi bersamaan dengan emosinya yang biasa meningkat dan pada akhirnya mereka sulit untuk menerima nasihat orang tua.

Pertumbuhan dan perubahan yang dialami oleh remaja membuat mereka mau tidak mau dituntut untuk bersikap dan berperilaku lebih dewasa dari sebelumnya. Hal ini meruapakan hal yang cukup sulit bagi remaja itu sendiri mengingat terjadi perubahan secara besar-besaran dalam kehidupan mereka. Tuntutan ini menjadi lebih kompleks dan harus dihadapi oleh mereka dan pada akhirnya membuat mereka tidak ingin disebut sebagai anakanak lagi dan berusaha untuk diakui dan dihargai serta diperlakukan sebagai orang dewasa. Oleh karena itu, pada masa ini, perkembangan remaja terpusat pada upaya untuk menanggulangi sikap dan pola perilaku kekanak-kanakan dan berusaha untuk menjadi orang dewasa.

Perkembangan yang dialami oleh remaja sebagaimana diketahui tidak hanya berpusat pada perkembangan pada fisik mereka saja, akan tetapi perkembangan dan pertumbungan serta perubahan yang harus dilalui oleh remaja meliputi semua aspek kehidupan mereka. Oleh karena itu, mereka harus berupaya keras untuk memenuhi dan beradaptasi dengan proses perkembangan dan perubahan tersebut. Pada masa ini, remaja sudah harus menerima keadaan fisiknya, menjalin hubungan baru dan lebih matang dengan teman sebaya antara dua jenis kelamin, beradaptasi dengan keadaan sesuai dengan jenis kelaminnya dan belajar hidup seperti bagaimana masyarakatnya hidup, memperoleh kebebasan emosional yang diperoleh dari orang tua dan orang dewasa lainnya, menjadi lebih mandiri dari segi finansialnya serta mampu menyerap nilai-nilai hidup dan falsafat hidup.

Saat ini tantangan yang dihadapi remaja sangatlah berbeda dari apa yang pernah dilalui orang tua mereka atau orang dewasa lainnya ketika mereka remaja. Penyebaran virus Covid-19 dan penetapannya sebagai sebuah pandemi, tentunya membawa banyak sekali perubahan dalam pola hidup mereka dan perubahan ini terjadi sangat cepat dan tak terbendung. Terjadinya perubahan yang bersifat cepat dan drastis ini membuat banyak pihak kebingungan dan tentunya hal ini juga menimpa para remaja. Bagaimana tidak, seluruh kegiatan keseharian harus mereka jalani di rumah. Sekolah yang merupakan rutinitas di mana mereka belajar, membangun mimpi mereka serta bergaul dengan teman sebayanya harus dipaksa libur dan beralih pada sistem daring. Mereka dipaksa berdiam diri di rumah dan melakukan semuanya di rumah.

Kondisi ini tentunya memberi dampak psikososial bagi remaja. Perasaan bosan karena terus berdiam diri di rumah tanpa bisa bertemu dengan teman-temannya, takut tertinggal pelajaran, merasa cemas akan tertular penyakit, timbul perasaan tidak aman, khawatir akan penghasilan orang tua mereka karena tidak sedikit orang tua yang harus kehilangan pekerjaannya selama pandemi ini berlangsung dan begitu pula dengan perasaan rindu akan teman-teman mereka di mana kita tahu bahwa masa-masa ini adalah masa di mana remaja secara aktif mulai membangun relasi dengan orang lain, khususnya teman sebayanya (COVID-19, n.d.). Hal ini tidak bisa dipungkiri karena memang emosi remaja sangat mudah terguncang. Oleh karena itu, kecemasan berlebihan,, ketakutan akan tertular virus dan sebagainya akan sangat mudah muncul dalam benak mereka (Dani \& Mediantara, 2020). Dampak-dampak ini juga mengacu pada usia remaja di mana mereka masih sangat labil dalam menghadapi kondisi-kondisi yang tak terduga (Tjukup et al., 2020). Keadaan ini diperparah dengan kurangnya informasi yang remaja terima terkait pandemi Covid-19 ini (Purwanto et al., 2020) dan ditambah dengan pemberitaan di media massa dan juga media 
sosial yang terlalu heboh (Aulia, 2018) serta kurangnya literasi mengenai penularan serta pencegahan virus Covid-19 ini (Fitria \& Ifdil, 2020).

Sebagaimana dijelaskan sebelumnya bahwa perubahan kondisi akibat pandemi Covid-19 ini membawa pengaruh besar pada keadaan emosi mereka. Perasaan irasional dan stress tidak bisa dihindarkan. Remaja sering kali mengalami fluktuasi emosi, mereka mudah marah, menangis, sering kali berperilaku yang tidak biasanya dan pada akhirnya memilih untuk mengurung diri di dalam kamarnya untuk mengusir kebosanannya, mudah khawatir akan sesuatu hal, berpikir bahwa terjadi sesuatu yang buruk di sekitarnya, mengalami gangguan tidur, kehilangan kepercayaan diri, mudah lelah dan tidak tertarik lagi dengan apa yang dulu digemarinya (Ananda \& Apsari, 2020).

Perasaan-perasaan negatif yang dirasakan remaja ini, khususnya bagaimana tingkat kecemasan sangat mempengaruhi mereka ini berdampak sekali pada kehidupan sehariharinya. Kecemasan berlebih akan berdampak pada intensitas waktu tidur yang menurun drastis dan menimbulkan insomnia (Sohat et al., 2014). Kecemasan ini juga memengaruhi kemampuan fokus belajar remaja di mana pemberitaan-pemberitaan serta kondisi yang ditimbulkan oleh pandemi ini membuat siswa kesulitan bahkan bisa kehilangan fokus belajar mereka (Hanifah et al., 2020) dan pada akhirnya kecemasan berlebih ini berpengaruh pada jangkauan memori remaja yang semakin menurun sehingga membuat mereka sering lupa akan pelajaran-pelajaran yang diterimanya (Hanifah et al., 2020).

Satu hal yang juga menjadi masalah besar bagi remaja selama pandemi ini adalah proses pembelajarannya (Purwanto et al., 2020). Sistem pembelajaran yang berubah secara tiba-tiba dan terjadi begitu cepat membuat mereka harus beradaptasi segera untuk memahami sistem pembelajaran baru tersebut, khususnya bagaimana mereka memahami materi-materi pembelajaran mereka. Sistem pembelajaran daring yang diterapkan oleh pemerintah ini membuat siswa sangat ketergantungan dengan hp mereka. Dampak yang ditimbulkan ketergantungan ini salah satunya adalah pada perkembangan fisik mereka (Aqilah \& Salmiati, 2020). Durasi penggunaan hp selama masa pandemi ini meningkat drastis dan ini membuat para remaja ini malas untuk bergerak. Mereka biasanya menghabiskan waktu dengan hp mereka dalam posisi duduk dan keseringan berbaring. Kebiasaan ini pada akhirnya menimbulkan penyakit-penyakit yang dulunya jarang mereka alami, seperti sakit kepala, gangguan penglihatan, kelainan postur tubuh dan berisiko terkena berbagai macam penyakit.

Selain dampak bagi kesehatan remaja, selama pandemi ini para remaja memiliki keleluasan untuk mengakses internet tanpa batas. Keleluasan akses ini memungkinkan para remaja ini menonton hal yang tidak patut bagi perkembangan karakter dan emosional mereka, dan bahkan para remaja ini kerap kali meniru tontonan yang tidak layak tersebut. Selain itu, maraknya berita bohong atau hoax tersebar luas dan dapat dikonsumsi publik secara bebas bisa berdampak lebih parah pada pola pikir remaja karena mereka bisa saja menganggap hal tersebut merupakan sebuah kebenaran. Akibat dari hal ini, remaja bisa jadi berperilaku menyimpang karena sifat mereka yang tidak kritis dan menelan mentah-mentah semua hal yang mereka terima. Kebiasaan seperti ini tentunya akan berdampak buruk pada minat belajar mereka, kompetensi, pengetahuan dan emosi serta akan sangat memengaruhi akhlak mereka (Aqilah \& Salmiati, 2020).

Proses pembelajaran daring yang dilakukan selama pandemi ini ternyata juga berdampak pada pendidikan remaja. Proses pembelajaran daring biasanya dilakukan hanya dengan satu arah dari guru ke siswa. Pada akhirnya proses pembelajaran semacam ini membuat remaja tertutup. Mereka merasa kesulitan untuk berinteraksi dan mengekspresikan diri dengan teman dan guru mereka di kehidupan nyata. Selain itu, pembelajaran daring ini membuat remaja sangat adiktif terhadap internet. Remaja yang sudah adiktif terhadap internet ini akan sangat kesulitan untuk berkonsentrasi terhadap pembelajaran karena pikirannya selalu tertuju pada sosial media dan juga permainan daring mereka. Keadaan ini 
pada akhirnya membuat mereka cuek, acuh tak acuh terhadap kewajiban mereka sebagai pelajar (Rini, 2011).

Dampak lain yang muncul selama pandemi ini adalah perubahan pada kepribadian remaja. Dampak yang ditimbulkan terhadap kepribadian adalah timbulnya rasa malas dalam melakukan sesuatu, serta kurangnya minat untuk bersosialisasi dengan teman atau keluarga. Paparan kekerasan dari game online serta tontonan mereka juga bisa membuat mereka menjadi lebih agresif pada orang lain (Rini, 2011). Remaja yang gemar bermain game online umumnya cenderung lebih suka melawan orang tua mereka, terutama ketika orang tuanya melarangnya untuk bermain game tersebut.

Dampak-dampak negatif yang ditimbulkan oleh pandemi Covid-19 terhadap remaja tentunya sangat mengkhawatirkan. Remaja merupakan tonggak penerus bangsa. Mereka adalah calon-calon pemimpin yang kelak akan membangun bangsa dan akan berkontribusi pada agama. Jikalau dampak-dampak negatif ini terus berlanjut, tanpa ditangani dengan serius, maka negara dan agama akan kehilangan pemimpin-pemimpinnya dan ini akan bedampak sangat buruk pada keberlangsungan negara dan agama di negara ini.

2. Pendidikan Agama Islam

Pendidikan dalam Islam merupakan suatu kewajiban bagi seluruh pemeluknya. Jika kita ingin merujuk pendidikan dalam konteks Islam, maka pertama-tama kita harus merujuk kepada bahasa yang digunakan dalam Islam ketika berbicara mengenai pendidikan. Kata "Pendidikan" dalam bahasa Arab umumnya merujuk pada istilah ta'lim, tarbiyah dan ta'dib.

Berkaitan dengan kata "tarbiyah", Abdurrahman al-Nahlawi, dalam (al-Nahlawi, 1989) berpendapat bahwa kata "tarbiyah" berasal dari tiga kata, yaitu: pertama, dari kata raba-yarbu yang berarti bertumbuh dan bertambah; kedua, rabiya-yarba yang berarti besar; ketiga, berasal dari kata rabba-yarubbu yang memiliki makna menguasai urusan, memperbaiki, menjaga, menuntun, dan memelihara. Kata ini sudah digunakan sejak zaman Nabi Muhammad saw. dan hal ini bisa terlihat diberbagai ayat Alquran dan juga dalam Hadis Nabi. Bentuk kata benda "rabba" ini juga digunakan untuk "Tuhan". Hal ini dikarenakan Tuhan juga bersifat mendidik, mengasuh, memelihara dan mencipta (Daradjat, 2007).

Kata "tarbiyah" yang diadopsi dari Alquran dan Hadis Nabi ini bukanlah hanya sebuah bentuk Pendidikan kognitif semata, tetapi juga merangkum Pendidikan emosional dan juga spiritual yang semuanya bermuara ke Alquran dan Hadis Nabi. Oleh karena itu, Pendidikan di sini diartikan dengan "proses transformasi ilmu pengetahuan dari pendidik kepada yang terdidik agar supaya yang terdidik ini memiliki sikap dan semangat yang tinggi dalam memahami dan menyadari eksistensi kehidupannya yang pada akhirnya akan membentuk pribadi yang bertakwa, memiliki budi pekerti dan kepribadian yang luhur" (Mujib \& Mudzakkir, 2006).

Adapun kata ta'lim menurut Abdul Fattah Jalal tidak berhenti pada pengerti pengetahuan yang lahiriah, begitu pula dengan pengetahuan taklid. Cakupan kata ta 'lim juga mengarah pada pengetahuan teoritis, mengulang kaji secara lisan serta adanya pengimplikasian dari teori tersebut. Ta'lim juga mencakup pengetahuan-pengetahuan lainnya di mana pengetahuan ini mencakup aspek-aspek keterampilan yang dibutuhkan dalam kehidupan sehari-hari yang mana dijadikan sebagai pedoman hidup (Jalal, 1988).

Istilah selanjutnya adalah $t a$ 'dib. Kata $t a$ 'dib dalam pengertian pendidikan menurut Sayid Muhammad al-Naquib al-Attas (Al-Attas (Syed), 1987) adalah pengenalan dan pengakuan yang berlangsung secara berangsur-angsur yang ditanamkan ke dalam manusia, tentang tempat-tempat yang tepat bagi segala sesuatu dalam tataran wujud sehingga hal ini akan membimbing ke arah pengenalan dan pengakuan terhadap tempat Tuhan yang tepat dalam tatanan wujud tersebut. Ta'dib ini lebih sering dikonotasikan dengan pendidikan sopan santun. Hal ini dikarenakan kata $t a$ 'dib seakar kata dengan kata adab yang memiliki pengertian pendidikan, peradaban atau berperadaban dalam artian bahwa orang yang berpendidikan adalah orang yang berperadaban. Melalui pengertian ini pendidikan lebih diarahkan sebagai sarana transformasi nilai-nilai akhlak mulai yang bersumber dari ajaran 
agama ke dalam diri manusia, serta hal ini menjadi dasar sebagai proses islamisasi segala ilmu pengetahuan (Munardji, 2004).

Berdasarkan definisi-definisi tersebut, pendidikan Islam merujuk pada bimbingan yang diberikan kepada seseorang agar ia tumbuh dan berkembang sesuai dengan ajaran agama Islam. Menurut al-Nahlawi (al-Nahlawi, 1989) pendidikan Islam merupakan penataan dan bimbingan individual dan sosial yang bertujuan untuk menjadikannya sebagai pribadi yang tunduk pada ajaran Islam dan kemudian menerapkannya dalam kehidupan pribadi maupun sosialnya. Hal ini sejalan dengan pendapat al-Shaybani (Shaybani, 1991) yang menyatakan bahwa Pendidikan Islam merupakan usaha untuk mengubah kepribadian seseorang berdasarkan pada nilai-nilai Islam dalam kehidupan pribadi, masyarakat maupun dalam kehidupannya yang bersangkutan dengan alam sekitarnya melalui proses pendidikan.

Pendidikan Islam memang sangat mementingkan akhlak dan budi pekerti seseorang. Lebih lanjut lagi, Pendidikan Islam bisa dikatakan sebagai pembentukan kepribadian Muslim (Daradjat, 2007). Hal ini dikarenakan Pendidikan Islam lebih merujuk pada perbaikan sikap dan perilaku yang di mana tujuan akhirnya adalah perwujudan ilmu-ilmu tersebut dalam bentuk amal perbuatan, baik itu ditujukan untuk kepentingan dirinya sendiri maupun untuk kepentingan orang lain. Hal ini mempertegas bahwa pendidikan Islam tidak berhenti pada pendidikan yang bersifat teoritis saja, tetapi juga meliputi aspek praktis. Dalam Islam setiap ilmu pengetahuan tidak pernah memisahkan antara iman dan amal. Oleh karena itu, pendidikan Islam berisi tentang ajaran mengenai sikap dan tingkah laku di masyarakat, selalu memperhatikan keselarasan antara kepentingan pribadi dan juga kepentingan bersama.

Pendidikan Islam lebih berorientasi kepada bagaimana menciptakan manusia yang beriman dan meyakini suatu kebenaran dan berusaha untuk membuktikan kebenaran tersebut dengan bantuan akal, feeling, rasa dan memiliki kemampuan untuk merealisasikannya dalam kehidupannya melalui amal shaleh ataupun perbuatan yang benar dan tepat.

Kehadiran pendidikan Islam memang sangat cocok dan dibutuhkan dalam menciptakan dan menumbuhkan pribadi yang berbudi pekerti luhur. Berkenaan dengan ini al-Syaibani dalam (Tafsir, 2010) menegaskan bahwa tujuan pendidikan Islam setidaknya bisa dijabarkan ke beberapa poin yang berkaitan dengan manusia itu sendiri, yakni: 1) berkaitan dengan individu, hal ini berarti bahwa pendidikan Islam mencakup segala perubahan berupa pengetahuan, tingkah laku, jasmani dan rohani, dan kemampuankemampuan yang dibutuhkan selama hidup di dunia dan akhirat; 2) berkaitan dengan masyarakat, ini berarti dalam pendidikan Islam pun mencakup setiap tingkah laku individu dalam masyarakat, bagaimana hidup berdampingan dalam kehidupan bermasyarakat dan memperkaya pengetahuan dan pengalaman masyarakat; 3) berkaitan dengan professional, hal ini lebih mematenkan pendidikan Islam sebagai ilmu, seni profesi dan sebagai kegiatan masyarakat.

Mahmud Yunus (Yunus, 1983) mengatakan bahwa pendidikan Islam bertujuan untuk mendidik anak-anak, remaja, orang dewasa agar supaya mereka menjadi seorang muslim sejati, memiliki iman yang teguh, beramal shaleh dan berakhlak mulia, sehingga ia mampu hidup mandiri di bawah kakinya sendiri, menghamba kepada Allah, berbakti kepada orang tua, negara dan bangsanya, bahkan ia bisa bermanfaat bagi umat manusia. Pendidikan Islam memang lebih bertujuan untuk menumbuhkan dan meningkatkan keimanan seseorang melalui pemupukan dan pemberian ilmu pengetahuan, penghayatan serta pengimplementasian agama Islam sehingga anak didik kelak akan menjadi seorang muslim yang terus menerus mengalami perkembangan keimanan, ketaqwaan, berbangsa dan bernegara (Majid, 2004).

Berdasarkan penjelasan-penjelasan di atas dapat disimpulkan bahwa pendidikan Islam baik dari segi makna maupun tujuannya selalu mengacu pada penanaman nilai-nilai Islam yang tidak hanya berpusat pada pemenuhan kewajiban dalam peribadatan, tetapi juga sangat menjunjung tinggi moral dan etika sosial dalam kerangka akhlak mulia. Penanam 
nilai-nilai Islam ini dalam rangka mempersiapkan anak didik untuk meraih kebahagiaan di dunia begitu pula kebahagian di akhirat kelak.

3. Pendidikan Agama Islam dan Remaja di Masa Pandemi

Agama dan manusia merupakan dua hal yang tidak bisa dipisahkan. Kebermaknaan kehidupan manusia sangat bergantung pada faktor agama. Agama mengandung banyak hal yang dibutuhkan oleh manusia, mulai dari aspek keyakinan, tata aturan peribadatan, dan tata nilai moral, yang mana semua hal tersebut berimplikasi dalam kehidupan sehari-hari. Agama telah menjadi kebutuhan dasar bagi setiap manusia jika mereka ingin menjadikan hidup dan kehidupan ini bermakna (Hude, 2015).

Manusia dalam hidupnya selalu membutuhkan agama dan butuh untuk berketuhanan. Manusia pada umumnya mempunyai dua kebutuhan. Pertama, kebutuhan material dan kedua, kebutuhan spiritual. Berkenaan dengan hal ini, Murthada Muthahari (Mutahhari, 1986) menyimpulkan bahwa pada hakikatnya agama memiliki dua keistimewaan, yaitu agama merupakan kebutuhan lahir dan batin manusia. Ia menegaskan bahwa kebutuhan manusia akan agama tidak dapat digantikan oleh apapun.

Al-Shaybani (Shaybani, 1991) menyatakan bahwa manusia memiliki kecenderungan untuk beriman kepada kekuasaan yang tertinggi dan paling tinggi yang menguasai alam raya ini. Kecenderungan ini sudah dibawanya sejak lahir. Kecenderungan untuk beragama ini semakin meningkat sejalan dengan meningkatnya taraf pemikirannya dan pada akhirnya manusia akan mengakui dan meyakini bahwa Tuhan itu ada. Ia juga memaparkan temuan Henry Bergson yang mengemukakan bahwa mungkin saja terdapat satu kelompok yang tidak memiliki sains, seni maupun filsafat, tetapi tidak ada satu kelompok pun yang tidak beragama (Shaybani, 1991). Erich Fromm (Fromm, 2013) menyatakan bahwa pengabdian kepada sesuatu yang transenden adalah suatu ekspresi kebutuhan akan kesempurnaan hidup. Oleh karena itu, tidak ada seorang pun yang tidak membutuhkan agama. Agama dibutuhkan oleh manusia sebagai kerangka orientasi dan objek pengabdian dalam kesempurnaan hidupnya.

Kebutuhan manusia akan hadirnya agama dalam kehidupan mereka sangat penting guna untuk menata dan menyempurnakan kehidupannya. Hal ini juga sangat berlaku bagi para remaja, bukan hanya karena mereka termasuk ke dalam bagian manusia, tetapi lebih kepada rentan usia mereka merupakan rentan usia yang sangat membutuhkan peran agama dalam kehidupan mereka. Kemunculan dan penyebaran virus Covid-19 di seluruh dunia yang berakibat pada peralihan sistem pembelajaran dan penilaian dari sistem tatap muka di sekolah menjadi sistem daring yang dilakukan baik guru maupun siswa di rumah masingmasing sangat mempengaruhi kehidupan mereka.

Munculnya virus ini dan berubahnya menjadi pandemi menimbulkan banyak masalah baru dalam kehidupan remaja. Selama kurang lebih setahun pemberlakuan pembelajaran daring, para remaja bukan hanya mengalami gangguan kesehatan fisik semata, melainkan efek dari pandemi ini paling banyak mempengaruhi psikis dan mental mereka. Mulai dari sifat adiktif terhadap hp dan internet, gangguan depresi, stress, cemas dan bahkan tidak sedikit yang menderita gangguan sosial, kesulitan berkomunikasi, sering terjadi perdebatan dengan orang tua, sikap acuh tak acuh terhadap lingkungan sekitarnya dan masih banyak lagi.

Permasalahan-permasalahan yang diderita oleh para remaja ini tidak bisa diacuhkan begitu saja mengingat kondisi pandemi ini belum bisa dikonfirmasi kapan akan berakhir. Pengacuhan terhadap hal-hal ini akan bisa berakibat yang lebih buruk lagi jikalau tidak ditangani dengan serius. Oleh karena itu, dibutuhkan solusi yang tepat dalam menanggulangi permasalahan ini.

Pada hakikatnya setiap permasalahan yang dimiliki oleh manusia selalu memiliki solusi. Kehadiran agama dalam kehidupan remaja akan memberikan pengaruh besar dan memberikan dampak positif bagi kecarut-marutan hidup mereka saat ini. Dalam agama Islam, setiap hal, mulai dari hal terkecil sampai kepada hal yang paling serius, mulai dari 
aktifitas fisik, emosi hingga spiritual memiliki tuntunan dan bimbingannya. Islam merupakan agama yang sangat terperinci yang memperhatikan setiap inci dan detail kehidupan manusia. Oleh karena itu, penerapan dan pengimplementasian ajaran agama Islam merupakan solusi terbaik dalam mengatasi permasalahan yang sedang dialami remaja di masa pandemi saat ini dan pengamalan ini tentu saja harus didapati melalui pendidikan yang benar dan terarah.

Peraturan-peraturan yang terdapat dalam agama merupakan nilai-nilai tertinggi dalam hidup manusia, hal ini pun berlaku bagi remaja di mana norma-norma agama tetap selalu dianggap suci dan berasal dari Tuhan. Segala bentuk aturan yang ada dalam agama selalu baik dan bertujuan untuk pengembangan dan penyempurnaan diri manusia. Dalam Islam terdapat kewajiban-kewajiban yang harus dilakukan oleh seseorang, baik itu untuk dirinya sendiri, orang tua, teman sejawat, masyarakat bahkan untuk negara sendiri Islam sudah sangat jelas mengatur semuanya. Begitu pula dengan hal-hal yang dilarang pun sudah diterangkan secara terperinci. Segala bentuk hubungan dalam kehidupan manusia memiliki aturan yang jelas dalam Islam. Oleh karena itu, pemahaman mendalam remaja terhadap agama, khususnya Islam akan mencegahnya untuk menyia-nyiakan hidupnya terhadap halhal yang tak berguna dan begitu pula akan menghindarkannya dari melakukan hal-hal buruk yang bisa merugikan dirinya, keluarga dan masyarakatnnya.

Remaja di masa pandemi ini tidak sedikit yang menjadi adiktif terhadap hp dan internet. Bagaimana tidak, sebelum pandemi ini terjadi sebagian besar waktu mereka habiskan di sekolah dan bercengkrama dengan teman-temannya, tetapi sekarang segala aktifitas mereka harus dilakukan di dalam rumah dan ditambah dengan proses pembelajaran dan penilaian sekolah yang juga dilaksanakan melalui sistem daring. Hal ini menyebabkan para remaja ini memilih untuk menghabiskan waktu mereka dengan memainkan hp. Penggunaan hp secara terus-menerus dalam jangka waktu yang panjang pada akhirnya membuat mereka sangat adiktif terhadap hp mereka. Sikap adiktif yang ditunjukkan oleh para remaja ini ternyata sangat berdampak pada kesehatan fisik maupun mental mereka.

Dalam Islam, kesehatan fisik sangat diperhatikan. Berdasarkan sejarah penegakan Islam, sejak awal penyebaran agama Islam para pemimpin Islam sudah memberikan pelatihan fisik terhadap kaum Muslim. Pendidikan-pendidikan fisik, berupa memanah, berenang, menggunakan senjata, menunggang kuda dan lari cepat sudah sangat ditekankan dalam Islam (Shaybani, 1991). Dalam Alquran surah al-Anfal ayat 60 disebutkan bahwa orang Islam harus selalu mempersiapkan kekuatan dan pasukan berkuda untuk menghadapi musuh Allah. Persiapan-persiapan ini salah satunya sangat menekankan pentingnya pendidikan fisik. Ada banyak sabda Nabi yang menekankan keterampilan fisik yang harus dimiliki oleh umat Islam, seperti memanah dan menunggang kuda. Umar bin Khattab pun memerintahkan kepada para gubernur di wilayah Islam untuk melatih anak-anak mereka berenang dan berkuda (Shaybani, 1991). Hal ini menegaskan bahwa dalam Islam, kesehatan fisik selalu menjadi perhatian dan hal ini didapatkan melalui pendidikan fisik sejak dini.

Pendidikan agama Islam memang memiliki fungsi sebagai persiapan generasi selanjutnya. Hal ini berarti bahwa pendidikan agama Islam dilaksanakan guna menyiapkan para remaja untuk memegang peranan tertentu dalam masyarakat di masa yang akan datang. Selain itu, para remaja ini akan diajarkan bagaimana mentransformasikan nilai yang dimiliki untuk memelihara kesatuan masyarakat, mengalihkan ilmu pengetahuan yang bersangkutan dengan peranan mereka kelak, dan bagaimana mendidik mereka agar mampu memiliki akhlak yang baik dalam lingkup sosialnya (Syafaat et al., 2008).

Selain itu pendidikan agama Islam berperan sebagai pembekalan, dalam artian bahwa pendidikan agama Islam diberikan kepada anak dan remaja untuk membimbing mereka untuk memiliki akhlak yang baik, membantu mereka memahami dan mendalami setiap prinsip-prinsip dan ajaran agama Islam agar nantinya mereka mampu menerapkannya dalam kehidupan sehari-hari. Pendidikan agama Islam juga hadir guna memberikan pemahaman 
kepada anak-anak dan remaja akan pemeliharaan diri mereka baik itu pemeliharaan secara fisik maupun psikis mereka (Daradjat, 2007).

Kecemasan, depresi dan berbagai jenis gangguan mental yang ditimbulkan oleh munculnya pandemi Covid-19 juga bisa diatasi melalui pendidikan agama Islam secara komprehensif. Pendidikan agama Islam bertujuan untuk mempersiapkan remaja beribadah kepada Allah. Beribadah di sini menurut Jalal (Jalal, 1988) bukan hanya bentuk ibadah mahdah yang mencakup shalat, puasa, zakat dan berbagai ibadah ritual lainnya. Akan tetapi, ibadah di sini lebih mengarah kepada segala aspek kehidupan yang dilakukan manusia, mulai dari perkataan, perbuatan, perasaan dan pemikiran. Pendidikan agama Islam akan membimbing agar para remaja tidak hanya mengetahui dan mengerti mengenai ajaran Islam, tetapi harus mengamalkannya dalam kehidupan sehari-harinya. Hal inilah yang bisa membantu para remaja dalam mengatasi segala bentuk kecemasan dan gangguan mental yang dialami selama pandemi karena ketika ajaran agama itu dilaksanakan dalam hidup, maka ia akan berpengaruh dan menentukan kesehatan mental mereka (Daradjat, 1988).

Berkaitan dengan hal ini, menurut Zakiyah (Daradjat, 2003) pembinaan jiwa agama benar-benar memperkuat jiwa remaja untuk menghadapi segala macam tantangan dan rintangan yang kelak akan mereka hadapi. Semakin banyak pengalaman yang bersifat agama dan semakin mendalam pengetahuan agamanya, maka tindakan, ucapan, sikap dan caranya menghadapi dunia akan sesuai dengan nilai agama. Lebih lanjut lagi, pendidikan agama yang ditanamkan sedini mungkin akan menjadi benteng moral yang kelak akan selalu mengawasi setiap tingkah laku dan jalan hidupnya dan menjadi obat gangguan jiwa (Daradjat, 1988).

Manusia membutuhkan tiang untuk bersandar kala ia sedang berada dalam kesulitan, menghadapi kegagalan, ataupun sedang mengalami hal yang tidak ia sukai. Di sinilah peran agama hadir sebagai sebuah kekuatan, rasa optimis dalam hidup serta memberi ketabahan di saat manusia berada dalam kesempitan dan kesulitan. Hal ini sebagaimana dijelaskan oleh Arnold Toybee dalam (Alim, 2011), dia menyatakan bahwa "Agama merupakan satu potensi esensi yang dialami oleh manusia dalam hidupnya, dan hal ini terjadi karena adanya keputusasaan rohani yang dialami oleh manusia yang memaksanya untuk mencari pelipur lara dari agama dan untuk menghadapi bencana dan segala permasalahan yang tidak mampu ia hadapi sendiri. Hal ini lebih dipertegas oleh pengalaman pribadi Karl Bang sebagai seorang ahli ilmu kedokteran dalam(Alim, 2011) mengenai bagaimana peran agama terhadap Kesehatan jiwa manusia. Menurutnya, setiap pasien yang datang kepadanya selama jangka kurun waktu tiga puluh tahun terakhir menyatakan bahwa fakta mereka menderita penyakit adalah karena mereka kehilangan akidah atau iman, sehingga hal ini mengakibatkan mereka sering menderita kegoncangan dan kegelisahan. Kondisi ini baru bisa teratasi setelah mereka Kembali beriman dan menjalankan ajaran agama kembali".

Dalam Islam, orang-orang beriman memiliki sandaran kuat ketika krisis dan badai paling berat sekalipun, karena bebannya akan dilimpahkan kepada walinya, yaitu Allah swt. Dalam Islam, istilah keputusasaan, kecemasan maupun segala bentuk penyakit-penyakit hati atau yang biasa diistilahkan dengan gangguan mental tidak ada dalam kamus orang beriman karena dalam Alquran banyak sekali tuntunan-tuntunan yang mengajarkan bagaimana seharusnya manusia berurusan dengan hal-hal tersebut, yaitu dengan mengingat Allah dan bersandar padanya.

Pendapat-pendapat di atas menguatkan pendapat bahwa hadirnya agama dalam kehidupan remaja, khususnya di masa pandemi ini akan menjadi solusi terbaik yang bisa diberikan untuk menangani segala bentuk gejala atau gangguan jiwa yang mereka derita. Kehadiran agama dalam hidup remaja ini tentunya hanya bisa diwujudkan melalui pendidikan agama Islam sedini dan setepat mungkin.

Permasalahan lain yang muncul dalam masa pandemi ini adalah perubahan perilaku remaja terhadap lingkungan sekitarnya. Berjalannya pandemi lebih dari setahun membuat perilaku remaja lebih tertutup dari lingkungan sekitarnya (Aqilah \& Salmiati, 2020). Mereka lebih sering mengurung diri di kamar dan lebih memainkan hp dan berselancar di dunia 
maya. Hal ini membuat mereka tidak hanya acuh terhadap nasihat orang tua mereka (Rini, 2011), tetapi mereka juga menjadi kurang peka dan kehilangan rasa sosial terhadap masyarakat dan lingkungan sekitar mereka.

Dalam konteks ini, perlu dipahami bahwa pendidikan agama Islam tidak hanya berfokus pada pengajaran dan pemahaman agama dan melatih keterampilan mereka dalam melaksanakan ibadah. Akan tetapi, pendidikan agama Islam lebih luas daripada itu, Pendidikan agama Islam lebih menitikberatkan pada bagaimana pembentukan kepribadian anak, sesuai dengan ajaran agama. Pendidikan moral, sikap dan perilaku jauh lebih penting daripada menghafal dalil-dalil dan hukum-hukum agama yang tidak diresapi dan dihayati dalam kehidupannya (Wardi, 2012). Dengan tertanamnya nilai dan ajaran agama dalam diri remaja, maka bisa dipastikan mereka tidak akan bertingkah yang tidak sesuai dengan nilai agama (Sudarsono, 2012). Mantapnya nilai agama dalam diri remaja akan menjadikan mereka lebih berhati-hati dalam berucap dan bertindak.

Penanaman keimanan kepada para remaja akan membantu mereka dalam menjauhi segala perilaku buruk yang kelak akan merugikan mereka dan orang lain. Keimanan merupakan salah satu penggerak pokok dalam tingkah laku seseorang, tanpa hadirnya rasa iman dalam hidup seseorang, maka mereka tidak memiliki batas mengenai hal yang harus mereka jaga. Jika seorang remaja sudah memiliki keimanan yang kuat dan tertanam dalam hatinya, maka segala tindakannya akan terkontrol dan ia pun tidak akan terjerumus dan melakukan hal-hal yang negatif (Syafaat et al., 2008).

Dalam pendidikan agama Islam, akhlak merupakan hal yang sangat dijunjung tinggi. Oleh karena itulah mengapa dalam Islam segala bentuk pendidikan tidak hanya terbatas dalam bentuk penjelasan semata, tetapi lebih pada uswah atau teladan dari orang tua, guru ataupun dari orang-orang tua di sekitarnya. Adanya peneladanan dari orang-orang yang lebih tua dari mereka mencontoh dan melakukan hal yang baik dan menjauhi hal yang kurang baik (Daradjat, 1994). Akhlak merupakan bentuk implementasi dari iman yang berbuah pada tingkah laku yang baik dalam kehidupan remaja. Oleh karena itu, hadirnya keimanan yang berbuah pada akhlak yang baik akan membantu remaja dalam bersosialisasi dalam kehidupan sosialnya di keluarga dan masyarakatnya.

\section{PENUTUP}

Permasalahan-permasalahan yang muncul selama pandemi Covid-19 yang mendera remaja tentunya sangat mengkhawatirkan. Mereka bukan hanya mendapat gangguan pada kesehatan fisik mereka, tetapi juga pandemi ini sangat mempengaruhi kondisi mental yang pada akhirnya mengganggu perilaku sosial para remaja tersebut. Gangguan-gangguan yang diterima oleh remaja selama pandemi ini akan bisa teratasi jikalau mereka menerima pendidikan agama Islam yang benar.

Pendidikan agama Islam yang tidak hanya berfokus pada hal-hal teoritis semata, namun lebih jauh kepada bagaimana nilai-nilai dan ajaran agama Islam bisa terealisasi dalam kehidupan remaja. Dalam Islam, pendidikan memiliki cakupan yang sangat luas, mulai dari pendidikan keimanan, fisik, mental hingga pada pendidikan akhlak. Oleh karena itu, pemberian pendidikan agama Islam bagi remaja di tengah-tengah masa pandemi ini akan bisa mengatasi segala permasalahan yang sedang mereka alami di masa pandemi ini.

\section{DAFTAR PUSTAKA}

2020 Children's Mental Health Report: Telehealth in an Increasingly Virtual World $\mid$ Child Mind Institute. (n.d.). Retrieved March 22, 2021, from https://childmind.org/ourimpact/childrens-mental-health-report/2020-childrens-mental-health-report/

Al-Nahlawi, A. (1989). Prinsip-prinsip dan Metode Pendidikan Islam dalam keluarga, di Sekolah dan di Masyarakat. Diponegoro.

Al-Attas (Syed), M. N. (1987). Konsep Pendidikan Dalam Islam. Mizan. 
Alim, M. (2011). Pendidikan Agama Islam: Upaya Pembentukan dan Kepribadian Muslim. PT Remaja Rosdakarya.

Ameliola, S., \& Nugraha, H. D. (2013). Perkembangan Media Informasi dan Teknologi Terhadap Anak dalam Era Globalisasi. Prosiding The 5th International Conference of Indonesian Studies: "Ethnicity and Globalization."

Ananda, S. S. D., \& Apsari, N. C. (2020). Mengatasi Stress Pada Remaja Saat Pandemi Covid19 Dengan Teknik Self Talk. Prosiding Penelitian dan Pengabdian kepada Masyarakat, 7(2), 248-256. https://doi.org/10.24198/jppm.v7i2.29050

Aqilah, N., \& Salmiati. (2020). Signifikansi Pendidikan Agama Islam Menghadapi Peroblematika Remaja Era Industri 4.0. Al-Ibrah, IX, 123-145.

Aulia, D. P. (2018). Memerangi Berita Bohong Di Media Sosial (Studi Terhadap Gerakan Masyarakat Anti Fitnah Indonesia) [Skripsi]. Universitas Islam Negeri Syarif Hidayatullah.

COVID-19, W. R. P. (2020). Lindungi Kesehatan Jiwa Anak dan Remaja Saat Masa Pandemi COVID-19-Berita Terkini. Covid19.Go.Id. Retrieved March 22, 2021, from https://covid19.go.id/p/berita/lindungi-kesehatan-jiwa-anak-dan-remaja-saat-masapandemi-covid-19

Dani, J. A., \& Mediantara, Y. (2020). Covid-19 dan Perubahan Komunikasi Sosial. Persepsi: Communication Journal, 3(1), 94-102. https://doi.org/10.30596/persepsi.v3i1.4510

Daradjat, Z. (1977). Pembinaan Remaja. Bulan Bintang.

------. (1988). Peranan Agama Dalam Kesehatan Mental. Haji Masagung.

(1994). Pendidikan Islam Dalam Keluarga Dan Sekolah. Ruhama.

. (2003). Ilmu Jiwa Agama. PT. Bulan Bintang.

. (2007). Ilmu Pendidikan Islam. Diterbitkan atas kerjasama Penerbit Bumi Aksara, Jakarta dengan Direktorat Jenderal Pembinaan Kelembagaan Agama Islam, Departemen Agama.

Fitria, L., \& Ifdil, I. (2020). Kecemasan Remaja Pada Masa Pandemi Covid -19. Jurnal EDUCATIO: Jurnal Pendidikan Indonesia, 6(1), 1-4. https://doi.org/10.29210/120202592

Fromm, E. (2013). Psychoanalysis and Religion. Open Road Media.

Hanifah, M., Yusuf Hasan, B., Nanda Noor, F., Tatang Agus, P., \& Muhammad, R. (2020). Kajian Jenis Kecemasan Masyarakat Cilacap dalam menghadapi Pandemi Covid 19. Kajian Jenis Kecemasan Masyarakat Cilacap dalam menghadapi Pandemi Covid 19. http://repository.unugha.ac.id/858/

Hude, M. D. (2015). Logika Al-Qur'an: Pemaknaan Ayat dalam Berbagai Tema. PT Nagakusuma Media Kreatif.

Jahja, Y. (2011). Psikologi Perkembangan. Kencana.

Jalal, A. F. (1988). Azaz-azaz Pendidikan Islam. Diponegoro.

Mahfuzh, S. M. J. (2001). Psikologi Anak dan Remaja Muslim. Pustaka Al-Kautsar.

Majid, A. (2004). Pendidikan Agama Islam Berbasis Kompetensi: Konsep dan Implementasi Kurikulum 2004. Remaja Rosdakarya.

Minarti, S. (2016). Ilmu Pendidikan Islam. Amzah.

Mujib, A., \& Mudzakkir, J. (2006). Ilmu Pendidikan Islam: Telaah Atas Kerangka Konseptual Pendidikan Islam. Kencana.

Munardji. (2004). Ilmu Pendidikan Islam. PT Bina Ilmu.

Mutahhari, M. (1986). Perspektif Al-Qur'an Tentang Manusia Dan Agama. Penerbit Mizan.

Nujuludin, H. D. (2017). Agama Membentuk Kepribadian Dan Gaya Kepemimpinan Pendidikan. Jurnal Pendidikan UNIGA, 7(1), 1-7.

Purwanto, A., Pramono, R., Asbari, M., Hyun, C. C., Wijayanti, L. M., Putri, R. S., \& Santoso, priyono B. (2020). Studi Eksploratif Dampak Pandemi COVID-19 Terhadap Proses Pembelajaran Online di Sekolah Dasar. EduPsyCouns: Journal of Education, Psychology and Counseling, 2(1), 1-12. 
Rini, A. (2011). Menanggulangi Kecanduan Game On-Line Pada Anak. Pustaka Mina.

Sarwono, S. W. (2012). Psikologi remaja. Rajawali Pers.

Shaybani, 'Umar Muhammad al-Tumi. (1991). Falsafah Pendidikan Islam. Bulan Bintang.

Sohat, F., Bidjuni, H., \& Kallo, V. (2014). Hubungan Tingkat Kecemasan Pada Lansia Di Balai Penyantunan Lanjut Usia Senja Cerah Paniki Kecamatan Mapanget Manado. JURNAL KEPERAWATAN, 2(2), Article https://ejournal.unsrat.ac.id/index.php/jkp/article/view/5163

Subur, S. (2016). Peran Pendidikan Agama Islam Dalam Perkembangan Jiwa Remaja. Jurnal Tarbiyatuna, 7(2), 167-184.

Sudarsono. (2012). Kenakalan Remaja: Prevensi, Rehabilitasi, dan Resosialisasi. Rineka Cipta.

Syafaat, A. dkk. (2008). Peranan Pendidikan Agama Islam Dalam Mencegah Kenakalan Remaja. PT RajaGrafindo Persada.

Tafsir, A. (2010). Ilmu Pendidikan Dalam Perspektif Islam. Remaja Rosdakarya.

Tjukup, I. K., Putra, I. P. R. A., Yustiawan, D. G. P., \& Usfunan, J. Z. (2020). Penguatan Karakter Sebagai Upaya Penanggulangan Kenakalan Remaja (Juvenile Delinquency). KERTHA WICAKSANA, 14(1), 29-38. https://doi.org/10.22225/kw.14.1.1551.29-38

Tohirin. (2005). Psikologi Pembelajaran Pendidikan Agama Islam: Berbasis Intergrasi dan Kompetensi. PT RajaGrafindo Persada.

Truzoli, R., Viganò, C., Galmozzi, P. G., \& Reed, P. (2020). Problematic Internet Use and Study Motivation in Higher Education. Journal of Computer Assisted Learning, 36(4), 480-486. https://doi.org/10.1111/jcal.12414

Wardi, M. (2012). Penerapan Nilai Pendidikan Agama Islam Dalam Perubahan Sosial Remaja. TADRIS: Jurnal Pendidikan Islam, 7(1), 31-44. https://doi.org/10.19105/tjpi.v7i1.377

Yunus, M. (1983). Metode Khusus Pendidikan Agama. PT Hidakarya Agung. 